\title{
Akuntabilitas Pengelolaan Dana BOS Di SDN Pringgowirawan 02 Kecamatan Sumberbaru Kabupaten Jember Tahun 2014
}

\section{(Accountability Of SOA Fund In Pringgowirawan 02 State Elementary School On Sumberbaru District, Jember Regency Year Of 2014)}

\author{
Tutus Julantika, Djoko Supatmoko, Taufik Kurrohman* \\ Jurusan Akuntansi, Fakultas Ekonomi, Universitas Jember (UNEJ) \\ Jln. Kalimantan 37, Jember 68121 \\ E-mail:mas_opiex@yahoo.com
}

\begin{abstract}
Abstrak
Penelitian ini bertujuan untuk mengetahui penerapan sistem Akuntabilitas dalam mengelola Dana Bantuan Operasional Sekolah (BOS) dan bagaimana bentuk pertanggungjwaban dana Bantuan Operasional Sekolah (BOS) di Sekolah Dasar Negeri Pringgowirawan 02 Kecamatan Sumberbaru tahun 2014. Metode Pengumpulan data yang digunakan dengan melakukan wawancara dengan Kepala Sekolah dan Bendahara BOS. Selain itu dilakukan Observasi langsung ke langsung ke lokasi Sekolah. Hasil penelitian ini adalah Pengelolaan dana BOS dinilai dari jumlah dana BOS yang direncanakan dengan dana BOS yang digunakan. Kesesuaian penggunaan di sini dilihat dari angka ratio yang ditunjukkan. Ratio dalam penelitian ini adalah angka yang menunjukkan kemampuan sekolah dalam menggunakan dana BOS sesuai dengan dana BOS yang sudah direncanakan di awal pembelajaran.
\end{abstract}

Kata Kunci: Akuntabilitas, Dana BOS, Pengelolaan Dana

\begin{abstract}
This research has two purposes i.e. to know the application of accountability system within the management of Accountability Of School Operational Assistance (BOS) fund and how the responsibility of Accountability Of School Operational Assistance (BOS) fund is used foward Pringgowirawan 02 Elementary school Sumberbaru in 2014 method of collecting data in the research is done through interview with the school principal and the chamberlain of Accountability Of School Operational Assistance (BOS). Besides, the researcher also uses direct observation foward the school area. The goal of this research is the management of Accountability Of School Operational Assistance (BOS) fund which is gained from the total planned and the total used of Accountability Of School Operational Assistance (BOS) fund itself. The compatibility of Accountability Of School Operational Assistance (BOS) fund used can be seen from the ratio shown. Ratio in this research is the number which is demonstrated the ability of school to use Accountability Of School Operational Assistance (BOS) fund based on the planned Accountability Of School Operational Assistance (BOS) fund in the earlier semester.
\end{abstract}

Keywords: Accountability, BOS Funds, Fund Management.

\section{Pendahuluan}

Pembangunan nasional merupakan usaha peningkatan sumber daya manusia dan masyarakat Indonesia yang dilakukan secara berkelajutan, berlandaskan kemampuan nasional, dengan memanfaatkan kemajuan ilmu pengetahuan dan teknologi serta memperhatikan tantangan perkembangan global. Mengingat sumber daya manusia merupakan salah satu aset nasional yang mendasar dan faktor penentu utama bagi keberhasilan pembangunan, maka dalam pelaksanaan pembangunan nasional yang pada hakikatnya untuk membangun manusia Indonesia seutuhnya dan seluruh masyarakat Indonesia harus memiliki landasan yang berdasar kepada Pancasila dan UUD 1945.

Pemerintah merupakan komponen terbesar dalam pembagian organisasi sektor publik. Organisasi sektor publik saat ini tengah menghadapi tekanan untuk lebih efisien, memperhitungkan biaya ekonomi dan biaya sosial, serta dampak negatif atas aktivitas yang dilakukan.

Akuntansi sektor publik merupakan akuntansi yang digunakan untuk organisasi nirlaba yang memiliki karakteristik tersendiri yang berbeda dengan perusahaan atau sektor privat. Akuntansi sektor publik terdiri atas akuntansi pemerintahan, akuntansi rumah sakit, akuntansi lembaga pendidikan, dan akuntansi organisasi nirlaba lain yang didirikan bukan untuk mencari keuntungan sematamata, tetapi sektor publik atau pemerintah dibentuk dengan tujuan umum memberikan pelayanan publik atau mensejahterakan rakyat.

Upaya yang paling strategis dalam peningkatan kualitas sumber daya manusia adalah dengan melalui pendidikan. Pendidikan sangat penting bagi Negara dan bangsa Indonesia, sebab dengan pendidikan kita dapat mencerdaskan kehidupan bangsa. Pendidikan akan berarti 
dan dapat meningkatkan kualitas sumber daya manusia bilamana pendidikan tersebut memiliki sistem yang berkualitas dan relevan dalam pembangunan. Oleh karena itu, kualitas pendidikan merupakan kebijakan dan program yang harus dilaksanakan secara optimal. Hal ini sesuai dengan tujuan Negara Indonesia yang tercermin dalam alenia keempat Pembukaan UUD 1945, yang menyatakan “.... Kemudian dari pada itu, untuk membentuk suatu pemerintahan Negara Indonesia yang melindungi segenap bangsa Indonesia, dan untuk memajukan kesejahteraaan umum, mencerdaskan kehidupan bangsa, dan ikut melaksanakan ketertiban dunia....”. untuk maksud mencerdaskan kehidupan bangsa dan meningkatkan kualitas sumber daya manusia yang relevan dalam pembangunan.

Undang-Undang Nomor 20 Tahun 2003 tentang Sistem Pendidikan Nasional mengamanatkan bahwa setiap warga negara yang berusia 7-15 tahun wajib mengikuti pendidikan dasar. Pasal 34 ayat 2 menyebutkan bahwa Pemerintah dan pemerintah daerah menjamin terselenggaranya wajib belajar minimal pada jenjang pendidikan dasar tanpa memungut biaya, sedangkan dalam ayat 3 menyebutkan bahwa wajib belajar merupakan tanggung jawab negara yang diselenggarakan oleh lembaga pendidikan Pemerintah, pemerintah daerah, dan masyarakat. Konsekuensi dari amanat undang-undang tersebut adalah Pemerintah dan pemerintah daerah wajib memberikan layanan pendidikan bagi seluruh peserta didik pada tingkat pendidikan dasar (SD dan SMP) serta satuan pendidikan lain yang sederajat.

Bidang pendidikan dalam rangka mewujudkan cita-cita pendidikan nasional, sampai saat ini pemerintah dihadapkan dengan berbagai permasalahan, seperti tingkat kualitas pendidik yang belum memenuhi standar mutu, sarana prasarana sekolah yang masih kurang memadai serta terbatasnya anggaran pendidikan yang disediakan oleh pemerintah dan banyak sekali ditemukannya berbagai masalah atau kendala pendanaan yang muncul. Selain itu, tantangan yang paling berat bagi bangsa Indonesia pada era globalisasi pada saat ini adalah bagaimana menyiapkan Sumber Daya Manusia yang cerdas, unggul dan berdaya saing agar mampu berkompetisi pada tingkat global.

Salah satu bentuk bantuan biaya pendidikan dari pemerintah bagi masyarakat ialah dana BOS (Bantuan Operasional Sekolah). Dana BOS ini ditujukan pada semua lembaga pendidikan dalam rangka wajib belajar pendidikan dasar 9 tahun. Dana BOS yang diberikan pemerintah digunakan untuk penyediaan pendanaan biaya operasional bagi satuan pendidikan dasar. Pemerintah berharap dengan adanya dana BOS ini semua lapisan masyarakat dapat mengikuti pendidikan tanpa perlu memikirkan biaya pendidikan. Pemerintah ingin Dana BOS yang telah diberikan dapat memenuhi kebutuhan para siswa dan tidak ada lagi pungutan untuk orang tua.

Sekolah sebagai suatu entitas sekolah harus mampu mengelola dana BOS secara profesional dan akuntabel untuk mendukung kegiatan belajar mengajar yang berkualitas. Dana BOS yang diberikan oleh pemerintah dikelola secara mandiri oleh pihak sekolah melalui Manajemen Berbasis Sekolah (MBS). Dari sisi manajemen keuangan, MBS menurut pengelola sekolah mampu melakukan perencanaan, melaksanakan, mengevaluasi dan mempertanggung jawabkan pengelolaan dana secara baik dan transparan. Pengelolaan dana yang baik tidak terlepas dari prinsip ekonomis, efisiensi, efektifitas, transparasi, akuntabilitas, keadilan, kejujuran dalam pengelolaan dan pengendalian.

Sehubungan dengan hal tersebut pemerintah mengeluarkan buku yang berisi petunjuk teknis tentang penggunaan dana BOS (Bantuan Operasional Sekolah) dan laporan keuangan bantuan operasional sekolah tiap tahunnya. Tujuan pemerintah menerbitkan buku petunjuk teknis setiap tahunnya agar pengelolaan dana BOS dilaksanakan dengan tertib administrasi, transparan, akuntabel, efisiensi dan efektifitas, tepat waktu, dan terhindar dari segala penyimpangan. Dengan adanya buku ini sekolah dapat mengerti cara menggunakan dan mempertanggungjawabkan dana tersebut kepada kepala dinas dan wali murid. Buku petunjuk teknis ini diterbitkan setiap tahun anggaran.

Buku petunjuk teknis ini memuat penjelesan mengenai penggunaan dana BOS yang meliputi organisasi pelaksana, prosedur pelaksanaan BOS, penggunaan dana BOS, monitoring dan supervisi, pengawasan, pemeriksaan dan sanksi, pengaduan masyarakat dan formulir isian. Selain penggunaan dana BOS juga ada tentang petunjuk laporan keuangan BOS yang meliputi perpajakan, pertanggungjawaban keuangan dan formulir isian. Tercantumnya semua peraturan dan petunjuk yang diberikan pemerintah diharapkan sekolah mampu mengelola dan menggunakan dana tersebut secara akuntabel.

Masalah baru muncul terkait dengan penyelewengan dana BOS, dan ketidakefektifan pengelolan dana BOS. Mulai dari pengalokasian dana tidak didasarkan pada kebutuhan sekolah tapi pada ketersediaan anggaran. Pada tingkat penyelenggara (Sekolah), tidak ada aturan mengenai mekanisme penyusunan anggaran. Penyebab lain juga terjadi pada partisipasi masyarakat yang kurang karena tidak memiliki akses untuk mendapat informasi mengenai anggaran sehingga mereka tidak bisa melakukan pengawasan. Jelas terlihat bahwa di dalam implementasinya, fungsi pengawasan sangat kurang. Tidak ada partisipasi dan akuntabilitas dalam proses pengelolaan dana BOS di sekolah. Keterbukaan informasi publik menjadi salah satu indikator kunci dalam implementasinya terkait dengan Dana BOS.

Akuntabilitas merupakan suatu parameter yang tidak dapat dipisahkan dari kuat atau lemahnya partisipasi masyarakat (Arifiyanto dan Kurrohman, 2014) yang dalam hal ini komite sekolah dan wali murid. Akuntabilitas merupakan landasan bagi proses pengelolaan dana BOS yang harus mempertanggung jawabkan tindakan dan pekerjaanya kepada masyarakat (komite sekolah dan wali murid). Akuntabilitas dalam pengelolaan dana BOS menyangkut hak masyarakat (wali murid) untuk memperoleh pertanggung jawaban penyelenggaraan program dana BOS.

Berdasakan hal tersebut di atas, penelitian ini berusaha untuk melakukan kajian lebih mendalam mengenai pertanggungjawaban pengelolaan anggaran Program Bantuan Operasional Sekolah (BOS). Permasalahan inilah yang dilaksanakan tidak menyimpang dari arah yang ditentukan. Yang perlu diperhatikan dalam pengelolaan 
anggaran dana BOS antara lain menganalisis program kegiatan dan prioritasnya, menganalisis dana yag ada dan mungkin bisa diadakan dari berbagai sumber pendapatan dan dari berbagai kegiatan. Oleh karena itu, adanya akuntabilitas sangat penting dilakukan terkait pengelolaan anggaran dana BOS di Sekolah Dasar Negeri Pringgowirawan 02 kecamatan Sumberbaru Kabupataen Jember dalam menciptakan Good Governance.

\section{Metode Penelitian}

\section{Jenis Penelitian}

Penelitian ini adalah penelitian deskriptif kualitatif. Menurut Sanusi (2011:13), desain penelitian deskriptif adalah desain penelitian yang disusun dalam rangka memberikan gambaran secara sistematis tentang informasi ilmiah yang berasal dari subyek atau obyek penelitian. Penelitian deskriptif berfokus pada penjelasan sistematis tentang fakta yang diperoleh saat penelitian dilakukan. Penelitian ini terbatas pada usaha mengembangkan suatu masalah atau keadaan untuk mengungkapkan fakta. Hasil penelitian ditekankan pada gambaran secara obyektif tentang keadaan sebenarnya dari objek yang diteliti.

\section{Lokasi Penelitian}

Penelitian ini dilaksanakan di Sekolah Dasar Negeri Pringgowirawan 02 Jember. Sekolah Dasar Negeri Pringgowirawan 02 Jember merupakan salah satu Sekolah Dasar yang berada di Kecamatan Sumberbaru Kabupaten Jember. Penelitian ini dilakukan di Sekolah Dasar Negeri Pringgowirawan 02 Jember, hal ini dikarenakan pada Sekolah Dasar Negeri Pringgowirawan 02 Jember terletak pada daerah pinggiran Kabupaten Jember, sehingga dibutuhkan pertanggungjawaban yang tinggi. Penelitian ini fokus pada bentuk akuntabilitas pengelolaan dana Bantuan Operasional Sekolah (BOS). Penelitian pengelolaan dana Bantuan Operasional Sekolah (BOS) ini difokuskan pada penerapan sistem akuntabilitas Bantuan Operasional Sekolah (BOS) dalam tahap perencanaan, pelaksanaan dan pertanggungjawaban.

\section{Instrumen Penelitian}

Untuk memperoleh data dan informasi yang valid dan akurat, dilakukan wawancara secara mendalam, terhadap informan-informan yang dijadikan sumber informasi. Sedangkan informan yang dipilih peneliti adalah informan yang terlibat langsung serta memahami dan dapat memberikan informasi (gambaran) tentang pengelolaan Alokasi Bantuan Operasional Sekolah (BOS), yaitu Kepala Sekolah dan Bendahara BOS.

\section{Data dan Sumber Data}

Sumber data dibagi menjadi dua jenis yaitu:

a. Data Primer Adalah data yang diperoleh langsung dari sumbernya dengan cara interview/wawancara terstruktur.

b. Data Sekunder Adalah data yang diperoleh dari pihak ketiga atau literature, dokumentasi.

\section{Teknik Pengumpulan Data}

Teknik pengumpulan data yang digunakan dalam penelitian ini adalah sebagai berikut (Sugiyono, 2008:65):

1. Wawancara Tersetruktur adalah cara pengumpulan data dimana peneliti mengajukan pertanyaan kepada informan dalam bentuk lisan yang telah disiapkan berupa pertanyaan-pertanyaan. Peneliti melakukan wawancara langsung kepada informan baik itu dari pihak kepala sekolah, bendahara, maupun kurikulun yang berkompeten di dalam pengelolaan Bantuan Operasional Sekolah (BOS). Hasil wawancara tersebut terekam didalam alat perekem serta mencatat informasi yang kemudian dijadikan hasil penelitian

2. Dokumentasi adalah teknik pengumpulan data sekunder dengan mengidentifikasi data yang diperoleh dari dokumen.

\section{Pengujian Keabsahan Data}

\section{Uji Kredibilitas}

Menurut pendapat Moleong (2011:45), memaparkan tujuan uji (credibility) kredibilitas data yaitu untuk menilai kebenaran dari temuan penelitian kualitatif. Kredibilitas ditunjukkan ketika partisipan mengungkapkan bahwa transkrip penelitian memang benar-benar sebagai pengalaman dirinya sendiri. Dalam hal ini peneliti akan memberikan data yang telah ditranskripkan untuk dibaca ulang oleh partisipan. Kredibilitas menunjukkan kepercayaan terhadap data hasil penelitian kualitatif. Bermacam-macam cara pengujian krediilitas data, namun dalam penelitian ini hanya menggunakan teknik triangulasi.

\section{Teknik Triangulasi}

Menurut Sugiyono (2008:241), dalam teknik pengumpulan data, triangulasi diartikan sebagai teknik pengumpulan data yang bersifat menggabungkan dari berbagai teknik pengumpulan data dan sumber data yang diperoleh. Bila peneliti menggunakan teknik triangulasi, maka sebenarnya peneliti mengumpulkan data sekaligus menguji kredibilitas data, yaitu mengecek kredibilitas data dengan berbagai teknik pengumpulan data dan berbagai sumber data. Triangulasi yaitu menggunakan teknik pengumpulan data dari sumber yang sama. Peneliti menggunakan teknik wawancara secara mendalam dan dokumentasi untuk sumber data yang sama secara serempak. Hal ini dapat dicapai dengan jalan:
a. Membandingkan data hasil pengamatan dengan data hasil wawancara.
b.Membandingkan apa yang dikatakan orang didepan umum dengan apa yang dikatan secara pribadi.
c.Membandingkan hasil wawancara dengan isi suatu dokumentasi yang berkaitan.
Jadi, teknik triangulasi yang dilakukan dalam penelitian ini yaitu membandingkan hasil pengamatan dan hasil data dari dokumen yang diperoleh dengan wawancara yang dilakukan dengan pihak yang terkait.

\section{Teknik Analisa Data}

Menurut Sugiyono (2008: 244), yang dimaksudkan dengan analisis data adalah proses untuk mencari dan menyusun secara sistematis data yang diproleh dari wawancara, dan catatan kecil dilapangan. Dalam penelitian ini, analisis data disederhanakan dengan tahapan-tahapan sebagai berikut. Tahapan pertama mengindentifikasi data yang diperoleh dari lapangan, baik dengan cara wawancara, maupun dokumentasi, yang bersumber dari buku, literature, dan 
foto. Tahapan kedua, yakni mengklasifikasikan data yang masuk, kemudian disesuaikan dengan permasalahan dan tujuan penelitian. Tahapan ketiga, yakni melakukan interpretatif terhadap faktor yang mempengaruhi.

\section{Hasil dan Pembahasan}

Pengelolaan dana BOS SDN Pringgowirawan 02 Kecamatan Sumberbaru Kabupaten Jember tahun 2014 pada penelitian ini dinilai dari jumlah dana BOS yang direncanakan dengan dana BOS yang digunakan. Kesesuaian penggunaan di sini dilihat dari angka ratio yang ditunjukkan. Ratio dalam penelitian ini adalah angka yang menunjukkan kemampuan sekolah dalam menggunakan dana BOS sesuai dengan dana BOS yang sudah direncanakan di awal pembelajaran. Berikut merupakan tabel yang menunjukkan angka ratio yang diperoleh sekolah pada tahun 2014.

Tabel. Rasio Antara Perencanaan dan Penggunaan BOS SDN Pringgowirawan 02 Kecamatan Sumberbaru Kabupaten Jember Bulan Januari - Juni tahun Anggaran 2014

\begin{tabular}{|c|c|c|c|c|}
\hline $\begin{array}{l}\text { No. } \\
\text { Kode }\end{array}$ & Uraian Kegiatan & Perencanaan & Penggunaan & Ratio \\
\hline 1.1 & $\begin{array}{l}\text { Pengembangan Kompetensi } \\
\text { Lulusan }\end{array}$ & Rp0 & Rp0 & 0 \\
\hline 2.1 & Pengembangan Standar Isi & $\operatorname{Rp} 2.500 .000$ & $\operatorname{Rp} 2.500 .000$ & $1: 1$ \\
\hline 3.1 & Pengembangan Standar Proses & $\operatorname{Rp} 7.490 .000$ & Rp6.012.000 & $1: 0,8$ \\
\hline 4.1 & $\begin{array}{l}\text { Pengembangan Pendidik dan } \\
\text { tenaga kependidikan }\end{array}$ & $\operatorname{Rp} 500.000$ & $\operatorname{Rp} 450.000$ & $1: 0.9$ \\
\hline 5.1 & $\begin{array}{l}\text { Pengembangan sarana dan } \\
\text { prasarana sekolah }\end{array}$ & $\operatorname{Rp} 21.793 .000$ & Rp17.263.000 & $1: 0,81$ \\
\hline 6.1 & $\begin{array}{l}\text { Pengembangan standar } \\
\text { pengelolaan }\end{array}$ & Rp5.411.000 & Rp6.150.000 & $1: 1,14$ \\
\hline 7.1 & $\begin{array}{l}\text { Pengembangan standar } \\
\text { pembiayaan }\end{array}$ & $\operatorname{Rp} 23.853 .000$ & Rp22.301.000 & $1: 0,93$ \\
\hline 8.1 & $\begin{array}{l}\text { Pengembangan dan implementasi } \\
\text { sistem penilaian }\end{array}$ & Rp14.433.000 & Rp14.966.000 & $1: 1,04$ \\
\hline \multicolumn{2}{|c|}{ Jumlah } & Rp75.980.000 & Rp69.642.000 & $1: 0,92$ \\
\hline & Saldo & & Rp6.338.000 & \\
\hline
\end{tabular}

\section{Sumber: Data Primer Diolah}

Berdasarkan hasil perhitungan tersebut dapat diketahui bahwa pada bulan Januari - Juni tahun 2014 banyak kegiatan yang kurang sesuai dengan dana yang direncanakan pada awal pembelajaran. Pengembangan kompetensi lulusan memiliki rasio 0 . Hal ini berarti bahwa pada pengembangan kompetensi lulusan tidak terdapat anggaran yang direncanakan serta tidak ada pengeluaran yang dilakukan oleh pihak sekolah.

Satu tahun anggaran terdiri dari 2 semester. Oleh karena itu tahun anggaran 2014 untuk bulan Juli - Desember juga akan dianalisis serupa. Peneliti juga akan membandingkan dana yang direncanakan sekolah dengan dana yang digunakan oleh sekolah. Untuk mengetahui sistem akuntabilitas dalam pengelolaan yang dilakukan sekolah apakah disesuaikan dengan rencana kegiatan dan anggaran sekolah yang bersumber dari dana BOS atau masih terjadi selisih pada semester sebelumnya. Selain itu, apakah ada perubahan oleh sekolah dalam mengelola keuangan dana BOS agar mencapai sasaran yang tepat guna.

Berikut merupakan tabel yang menunjukkan besarnya perbandingan antara perencanaan dan penggunaan yang digunakan oleh SDN Pringgowirawan 02 Kecamatan Sumberbaru Kabupaten Jember pada bulan Juli Desember. Tabel ini akan diberikan ratio yang menunjukkan perbandingan antara perencanaan dan dana yang digunakan sekolah selama periode berjalan.

Dana BOS yang diterima oleh sekolah harus dibuatkan pembukuan sebagai bukti dari pihak-pihak yang bersangkutan yang terdiri dari pemerintah dan orang tua dari siswa siswi SDN Pringgowirawan 02 Jember. Pembukuan yang harus dibuat terdiri atas RKAS tiap semester, buku kas umum, buku pembantu kas, buku pembantu bank, buku pembantu pajak, dan realisasi anggaran tiap triwulan.

Berdasarkan keseluruhan pembukuan, hanya RKAS tiap semester dan realisasi tiap anggaran yang harus diterbitkan artinya pembukuan tersebut harus dipampang di sekolah dan diserahkan kepada wali murid pada setiap semester. Oleh karena itu kedua laporan tersebut harus memenuhi standar administrasi yang sudah ditentukan. Berdasarkan hasil pengamatan dan wawancara yang telah dilakukan, maka diperoleh data mengenai keterlaksanaan sekolah dalam pembuatan RKAS dan realisasi anggaran.

Laporan realisasi yang dibuat SDN Pringgowirawan 02 Kecamatan Sumberbaru Kabupaten Jember sudah disusun secara rapi, hanya saja terdapat beberapa kejanggalan yang peneliti rasa harus dibenahi oleh sekolah. Dimulai dari penulisan jumlah saldo pada tri wulan I,II,III, dan IV, dimana pada laporan tri wulan tersebut tidak dicantumkan jumlah saldo antara jumlah dana yang direncanakan dengan dana yang dikeluarkan oleh pihak sekolah. Pihak sekolah seharusnya mencantumkan saldo tersebut karena saldo merupakan bagian dari penerimaan sekolah.

Sistem akuntabilitas dalam mengelola dan Bantuan Operasional Sekolah (BOS) di SDN Pringgowirawan 02 Kecamatan Sumberbaru Kabupaten Jember sudah dapat dilaksanakan dengan cukup baik. Hal ini dapat dilihat dari hampir seimbangnya antara jumlah dana yang direncanakan dengan jumlah dana yang dikeluarkan dalam menjalankan berbagai kegiatan yang dilakukan di sekolah tersebut. Seperti halnya pada kegiatan Pengembangan Standar Isi yang mengalami ratio yang sama antara dana yang direncanakan dengan dana yang dikeluarkan dari semester 1 dan semester 2. Selain itu, pada Pengembangan sarana dan prasarana sekolah pada semester 2 juga mengalami keseimbangan antara dana yang direncanakan dengan dana yang dikeluarkan.

Hal ini dapat dilihat dari jumlah saldo pada semester 1 dan semester 2 yang jumlahnya tidak terlalu besar yaitu untuk semester 1 sebesar Rp 6.338.000 dan semester 2 sebesar Rp 300.900. Dimana jumlah tersebut akan digunakan untuk tambahan penerimaan pada semester selanjutnya. Hal tersebut sesuai dengan penjelasan dari bendahara BOS di SDN Pringgowirawan 02 Kecamatan Sumberbaru Kabupaten Jember yaitu saldo yang diperoleh pada semester 1 akan digunakan untuk menambah penerimaan pada semester yang berikutnya. Dimana adanya kelebihan 
dan kekurangan dana yang direncanakan dengan dana yang dikeluarkan masih dalam setandar yang sewajarnya, karena dana BOS yang diperoleh seluruhnya diperuntukkan bagi kegiatan sekolah.

Sedangkan pada semester 2 kegiatan yang mengalami kekurangan dana yaitu terdapat pada Pengembangan Kompetensi Lulusan. Hal ini dikarenakan pada semester 2 ini terutama pada bulan Agustus banyak pengeluaran biaya untuk kegiatan perlombaan. Selain itu kekuranagan yang lain juga terjadi pada Pengembangan standar pembiayaan dan Pengembangan dan implementasi sistem penilaian. Hal ini dikarenakan adanya pengeluran dana secara tidak terduga, seperti dalam upaya penggandaan soal ulangan harian serta pembelian bahan-bahan habis pakai.

Berdasarkan obeservasi dan wawancara yang telah dilakukan, dapat diketahui bahwa pihak SDN Pringgowirawan 02 Kecamatan Sumberbaru Kabupaten Jember sudah melakukan kewajibannya untuk menerbitkan laporan realisasi penggunaan dana BOS. Penerbitannya diserahkan kepada semua wali murid dan dipajang pada mading sekolah. Menurut beberapa wali murid, mereka sudah puas dengan laporan pertanggungjawaban yang diberikan sekolah kepada mereka. Hal ini dikarenakan sekolah selalu rutin dalam hal menerbitkan laporan tersebut.

Hal tersebut membuktikan bahwa SDN Pringgowirawan 02 Kecamatan Sumberbaru Kabupaten Jember telah menjalankan kewajibannya untuk menerbitkan realisasi penggunaan dana BOS. Untuk masalah laporan yang masih janggal dan rancu, pihak sekolah harus benar-benar memperhatikan lebih teliti lagi.

\section{Simpulan}

Bulan Juli - Desember penggunaan dana yang meningkat serta lebih besar dari pada dana yang direncanakan terjadi pada pengembangan kompetensi lulusan.
Hal ini dikarenakan pada program tersebut banyak kegiatan perlombaan yang harus diikuti, sehingga mengalami kekurangan dana sebesar Rp 1.798.9000,- karena banyak pengeluaran yang tidak terduga. Adanya kekurangan dana antara dana yang direncanakan dengan dana yang digunakan yaitu terjadi pada program Pengembangan standar pembiayaan yaitu sebesar Rp 501.500,-.

Laporan pertanggungjawaban yang meliputi RKAS dan realisasi penggunaan dana BOS sudah menerbitkan setiap semester baik diberikan kepada wali murid tiap acara pembagian raport maupun ditempel pada papan mading sekolah. Hanya saja realisasi sekolah harus dibenahi karena masih terdapat beberapa kerancuan pencatatan seperti tidak ditulis saldo pada laporan.

\section{Daftar Pustaka}

Afida. 2012. Pengolahan Dana Bantuan Operasional Sekolah (BOS) Ditinjau dari Akuntabilitas. Jember: Universitas Jember

Anwar Sanusi. 2011. Metode Penelitian Bisnis. Jakarta: Salemba Empat.

Arifiyanto, D.F, dan Kurrohman, T 2014. Akuntabilitas Pengelolaan Alokasi Dana Desa di Kabupaten Jember, Jurnal Riste Akuntansi dan Keuangan. Vol 2 No 3, Desember, UPI Bandung

Moleong. L.J. 2011. Metodologi Penelitian Kualitatif Edisi Revisi. Bandung: PT Remaja Rosdakarya

Sugiyono. 2008. Statistik Untuk Penelitian. Bandung: Alfabeta.

Sugiyono. 2009. Metode Penelitian Kuantitatif, Kualitatif dan $R \& D$. Bandung: Alfabeta

Sugiono, RKA dan Kurrohman, T. 2015. Pengaruh Ketepatan Dana, Kecukupan Dana dan Sasaran Penggunaan Dana Bantuan Operasional Sekolah Terhadap Peningkatan Prestasi Belajar Siswa Di Kabupaten Jember. E-Journal Ekonomi Binsis dan Akuntansi 2(1) 23-28, Jember

Undang-Undang Sistem Pendidikan Nasional Nomor 20 Tahun 2003. Bandung: Citra Umbara.

Undang-Undang Sistem Pendidikan Nasional Nomor 20 Tahun 2003 pasal 34 ayat 2. Bandung: Citra Umbara.

Undang-Undang Sistem Pendidikan Nasional Nomor 20 Tahun 200 pasal 34 ayat 3. Bandung: Citra Umbara. 